\title{
Why Stop at Two Opinions? Reply to McCrae (2020)
}

\section{Bleidorn, Wiebke}

2020

Bleidorn, W , Hill , P L , Back , M D , Denissen , J J A , Hennecke , M , Hopwood , C J , Jokela , M , Kandler , C , Lucas , R E , Luhmann , M , Orth , U , Wagner , J, Wrzus , C , Zimmermann , J \& Roberts , B 2020 , ' Why Stop at Two Opinions? Reply to McCrae (2020) '

, American Psychologist , vol. 75 , no. 5 , pp. 731-732 . https://doi.org/10.1037/amp0000676

http://hdl.handle.net/10138/324770

https://doi.org/10.1037/amp0000676

Downloaded from Helda, University of Helsinki institutional repository.

This is an electronic reprint of the original article.

This reprint may differ from the original in pagination and typographic detail.

Please cite the original version. 
Why stop at two opinions? - A reply to McCrae (2020)

Wiebke Bleidorn, University of California, Davis, United States

Patrick L. Hill, Washington University in St. Louis, United States

Mitja D. Back, Westfälische Wilhems-Universität Münster, Germany

Jaap J. A. Denissen, Utrecht University, The Netherlands

Marie Hennecke, Universität Siegen, Germany

Christopher J. Hopwood, University of California, Davis, United States

Markus Jokela, University of Helsinki, Finland

Christian Kandler, Universität Bremen, Germany

Richard E. Lucas, Michigan State University, United States

Maike Luhmann, Ruhr-Universität Bochum, Germany

Ulrich Orth, Universität Bern, Switzerland

Jenny Wagner, Universität Hamburg, Germany

Cornelia Wrzus, Universität Heidelberg, Germany

Johannes Zimmermann, Universität Kassel, Germany

Brent Roberts, University of Illinois at Urbana-Champaign, United States

Correspondence: Wiebke Bleidorn, Department of Psychology, University of California Davis, One Shields Avenue, Davis, CA 95616, United States. E-mail: wiebkebleidorn@gmail.com.The authors are members of the Personality Change Consortium (PCC). 


\begin{abstract}
McCrae (2020) argues that it is premature to explore interventions focused on personality change. In his commentary, he suggests that interventions should only be promoted if their effects in self-report data are confirmed by the additional opinion of informants. We agree with the essence of his position and would go further by envisioning a new framework for rigorous collaborative research on personality change (Bleidorn et al., 2020). We nevertheless maintain that policy makers would benefit from considering the additional opinion of personality scientists.
\end{abstract}


Reply to McCrae

In his commentary, McCrae (2020) argues that more definitive results are needed before concluding that personality changes through interventions. He specifically calls for additional evidence from independent informant ratings, and more generally recommends that multimethod assessments should be featured in research on personality change.

We couldn't agree more about the importance of informant-reports and other data sources, as well as the more general need for increased rigor in personality-change research. Indeed, we have recently argued that a thorough understanding of the sources, processes, and consequences of personality change requires a paradigmatic shift in personality research (Bleidorn et al., 2020; Wagner et al., 2020). In the field of genetics, major progress was achieved through the initiation of collaborative research consortia to conduct more rigorous large-scale studies that sampled the genome comprehensively (e.g., Sullivan, 2010). In establishing the Personality Change Consortium (PCC, http://personalitychange.ucdavis.edu/) - a consortium for the study of personality change - we aim to promote similar developments in research on personality change. Specifically, we envision large-scale collaborative and interdisciplinary research programs designed to derive maps of experiences, behaviors, and life paths that are associated with changes in personality traits.

The development of reliable and valid measures of personality change - including but not limiting to multi-method assessments, as highlighted by McCrae (2020) - represents one of the four pillars of this initiative. In addition to 1) valid measures of personality change, we also highlight the need for 2) large, diverse, and representative samples, 3) more frequent assessments of personality and potential sources of change related to the person, their genes, and their environments, and 4) more rigorous research methods including experimental and measurementburst designs (Bleidorn et al., 2020). 
This approach will require collaborative efforts of researchers with different skill sets and areas of expertise. Support and funding for this kind of initiative will be more likely to the degree that personality scientists are able to communicate the relevance of personality change to educators, policy makers, and other influential groups. Results of this new generation of personality change research have the potential to be a resource for policy makers. For both of these reasons, we maintain that there is considerable mutual benefit in linking research on personality change to public policy (Bleidorn, Hill, et al., 2019).

In sum, we fully agree with McCrae's suggestion that additional opinions matter; we specifically believe that adding personality psychology's opinion to public policy considerations would make for better research and better decisions. We hope that, ultimately, these efforts will contribute to transformative research on personality change that tangibly advances both theory and public welfare. 


\section{References}

Bleidorn, W., Hill, P. L., Back, M. D., Denissen, J. J. A., Hennecke, M., Hopwood, C. J. . . \& Roberts, B. (2019). The policy relevance of personality traits. American Psychologist, 74, 1056-1067.

Bleidorn, W., Hopwood, C. J., Back, M. D., Denissen, J. J., Hennecke, M., Jokela, M., ... \& Zimmermann, J. (2020). Longitudinal Experience-Wide Association Studies (LEWAS)A Framework for Studying Personality Change (in press). European Journal of Personality Psychology. Advance online publication, https://doi.org/10.1002/per.2247

McCrae, R. R. (2020). Get a Second Opinion: Comment on Bleidorn et al. (2019). American Psychologist.

Sullivan, P. F. (2010). The psychiatric GWAS consortium: big science comes to psychiatry. Neuron, 68, 182-186.

Wagner, J., Orth, U., Bleidorn, W., Hopwood, C., \& Kandler, C. (2020). Towards an Integrative Model of Sources of Personality Stability and Change. Current Directions in Psychological Science. 